https://helda.helsinki.fi

\title{
Pedagogical documentation and its relation to everyday activities in early years
}

\section{Rintakorpi, Kati}

2017

Rintakorpi , K \& Reunamo , J 2017 , ' Pedagogical documentation and its relation to everyday activities in early years ' , Early Child Development and Care , vol. 187, no. 11 , pp. 1611-1622 . https://doi.org/10.1080/03004430.2016.1178637

http://hdl.handle.net/10138/308973

https://doi.org/10.1080/03004430.2016.1178637

unspecified

acceptedVersion

Downloaded from Helda, University of Helsinki institutional repository.

This is an electronic reprint of the original article.

This reprint may differ from the original in pagination and typographic detail.

Please cite the original version. 


\title{
Pedagogical documentation and their relation to everyday activities in early years
}

\author{
Kati Rintakorpi* and Jyrki Reunamo
}

Kati Rintakorpi, Department of Teacher Education, University of Helsinki, Finland. P.O. Box 9, FI00014 University of Helsinki, Finland, tel. +358-50- 5877316, kati.rintakorpi@ helsinki.fi.

Jyrki Reunamo, Department of Teacher Education, University of Helsinki, Finland. P.O. Box 9, FI00014 University of Helsinki, Finland, tel. +358-50-3183987, jyrki.reunamo@helsinki.fi.

Acknowledgements:

This research project has been funded by the Finnish Ministry of Education and Culture 2014-2016 and by the Ebeneser Foundation's Siiri Walli grant.

Biographical note:

Kati Rintakorpi, MEd, has 20 years of experience as a kindergarten teacher and manager, and now she is writing her dissertation on pedagogical documentation at the University of Helsinki, Finland. She is interested in comprehensive and child-centred approaches to ECEC including e.g. media education, arts education and ECEC policy. Rintakorpi's publications and activities are listed at https://tuhat.halvi.helsinki.fi/portal/en/persons/kati-rintakorpi\%284dbd3c46-4a10-41d5-b3163aa669012ced\%29.html

Jyrki Reunamo, PhD, is a docent and university lecturer at the University of Helsinki, Finland. His research interests include early childhood, research methods, information technology, sustainable education, physical education and language. He is the director of the Orientation project (http://blogs.helsinki.fi/orientate/), an early childhood research and development project. Reunamo's publications, activities and projects are listed at https://tuhat.halvi.helsinki.fi/portal/en/searchall.html?searchall=reunamo.

* Corresponding author 


\title{
Pedagogical documentation and their relation to everyday activities in early years
}

\begin{abstract}
Documentation in early childhood education and care (ECEC) institutions has been developed for decades in various contexts. Today documentation is preferred as an inclusive method of evaluating, planning and developing ECEC in the curricula of many countries. Qualitative research on documentation has increased in past years but quantitative research on the connections between documentation and ECEC practice has remained behind. We will present a study in which altogether 2,889 children, 194 kindergartens and preschools, and 179 teams of ECEC educators in 13 municipalities in Finland participated. On the basis of our quantitative analysis we argue that documentation is inherently connected with child-centred and carefully planned ECEC practices, the children's participation, wellbeing, and ability to learn. One of our main findings is that documentation is not yet fully exploited in the Finnish ECEC. As a result, we encourage ECEC officers and educators to develop documentation further.
\end{abstract}

Keywords: pedagogical documentation; early childhood education; quantitative study; Finland; participation

\section{Introduction}

The purpose of this article is to describe the relations between pedagogical documentation (PD) and children's everyday activities. We do this mainly by studying the correlations between the amount of PD usage and the observed children's activities.

Quantitative study of the connections between PD and children's everyday action has been rare. The evaluation of PD usage and observation were measured with independent measures and large-scale data.

In ECEC environments, documentation has long roots as a method for recording things that seem important from the viewpoint of preserving, assessing and developing ECEC practices (Lenz Taguchi, 2000, pp. 26-17; Dahlberg, Moss, \& Pence, 2007, p. 145; Emilson 
\& Pramling Samuelsson, 2014). Researchers, teachers, parents, and children themselves have photographed, videotaped, and transcribed various observations, feelings, experiences, questions and findings, discussions, agreements, learning, needs, and skills to revisit the situations later (see e.g. Schulz, 2015; Rintakorpi, Lipponen, \& Reunamo, 2014; Carr \& Lee, 2012; Clark, 2010; Project Zero, 2001). If the documents are utilized to study and develop pedagogy, we can speak about pedagogical documentation (Dahlberg et al., 2007, p. 145; Alasuutari, Markström, \& Vallberg-Roth, 2014, p. 31; Emilson \& Pramling Samuelsson, 2014). Currently in the curricula, documentation is considered to be the main way to assess and develop ECEC pedagogy in many countries, and its popularity amongst ECEC practitioners increases continually (Alasuutari et al., 2014, p. 18; OECD, 2011).

However, PD is not simply about practical implementation. Indeed, its implications in practice easily remain thin (Alasuutari, 2015; Alasuutari et al., 2014, pp. 125-126; Rintakorpi et al., 2014). PD demands the educators' time, understanding, theoretical knowledge about learning and child development, social and technical skills and equipment. Most important of all, PD demands diverse interpretations and a meaning-making process to achieve validity, reliability, and an ethical approach (Moss, 2005). If PD is applied fully, it might change the way the educators and ECEC communities understand the concepts of child, learning, and teaching (Rinaldi, 1998, pp. 121-122; Lenz Taguchi, 2000, p. 293; Rintakorpi, 2016). At the same time, the educators' approach to understanding those concepts have major implications for how they understand and use documentation in their ECEC practice. The concept of PD is not univocal. For example, if the educators see children as objects of adults' activity, they tend to focus on observing the development of the children and collecting evidence about their performance. But, if educators instead see children as subjects of their own life and learning, documentation offers possibilities to construct common understanding and knowledge about what is going on, what the world is like, where to head next, and which 
methods and tools to use in pedagogical endeavours and activities (Moss, 2005; Alasuutari et al., 2014, Emilson \& Pramling Samuelsson, 2014). Naturally, the approach of the local curricula determines how educators perceive the objectives of their work: the infant school approach focuses the school readiness of the children (Anglo-Saxon tradition) and the social pedagogic approach curriculum focuses on the whole child (Nordic tradition) (Bennett, 2010).

Research on PD has increased during the past few years. Yet, the research around the issue has been almost exclusively based on qualitative data, and the results have not been generalized for that reason. Moreover, the research has focused primarily on the question of how - by which tools and methods - to "listen to the voices of young children" (Schiller \& Einarsdottir, 2009). In the professional literature and practice, listening to the voices of children has often been regarded as synonymous with involving children in planning, assessing and decision making in ECEC, which is thought to automatically improve the quality of early childhood education (ECE). It is not evident that anything changes in ECE practice due to the documentation work. Critical voices have been heard about the validity, reliability and ethics of PD (Alasuutari et al., 2014; Blaiklock, 2008). It has been studied, for example, that the individual educational plans neither capture nor carry the child's or the parent's voice into the practical activities (Alasuutari \& Karila, 2010). In this article we ask what the practical connections are between adopting PD for both real and children's experiences. In other words, is PD a valuable enough practice to broaden the scope of its contemporary practices?

At this time, the research has discovered positive implications for documentation on democracy, participation, integrated-learning methods, assessment, and planning by using qualitative research methods (cf. Carr \& Lee, 2012; Clark, 2010; Fleer \& Hedegaard, 2010). Now, the objective of our study is to discuss the issue of PD by using extensive quantitative 
data to analyse if the documentation is strong (Ferraris 2013, p. 267; Alasuutari, 2015). This means, in other words, that the documentation has a concrete impact on ECEC practices. We are interested in how documentation is related to children' observed actions, learning and the learning environment (LE). We consider documentation done by educators, children and PD application in developing and planning the activities in ECEC. Our study combines the educators' different views about documentation, e.g. standardised tests, observations, and portfolios (OECD, 2011), all under the same umbrella of documentation.

\section{Method}

We present data, which are part of a larger study called the Orientation Project (http://blogs.helsinki.fi/orientate/), which is an early childhood education research and development project conducted in Finland, Hong Kong, Singapore and Taiwan. The project includes comparative research and LE development based on research results. Our Finnish data consist of observations, child evaluations and LE evaluations. The research questions are as follows:

1. To which LE qualities is documentation related?

2. To which observed activities and learning is documentation related?

3. How is documentation related to children's observed skills and qualities evaluated by the teachers?

\section{Participants}

Altogether, 194 kindergartens and preschools (for simplicity we use the word kindergarten for all institutions in this article, because the preschools were usually a part of a kindergarten) participated in the research in 13 municipalities in Finland. Between January and May 2015, altogether 2,889 children were observed with systematic sampling. The teachers evaluated children's skills, social orientation and self-regulation. Almost every child 
was evaluated, but due to an unfortunate mistake (the same numbers were distributed to different groups), only the evaluations of 2,312 children could be merged with the LE evaluations and observations. The LE evaluation forms were filled in by 179 (92\%) of the teams of ECEC practitioners. All the municipalities were in southern Finland. In some municipalities all kindergartens participated in the research, in some municipalities a sample of each participated, in some municipalities the administration picked a random sample of the kindergartens, in one municipality, all kindergartens from a certain area participated in the research. Thus, the sample may not be totally random even though the principles of random sampling were utilized. For example, the private kindergartens in the municipalities did not usually participate. Some kindergartens also refused, for example, because they were moving to another location or cancelled, because of sudden renovations due to indoor air quality problems. One team typically constitutes one kindergarten teacher and two ECEC nurses, but the exact number of participants is not available. The children were in kindergartens divided shared into 194 groups where their age range was from 13 to 102 months with the mean value being 67 months and the standard deviation was 18.9 months. The number of children in the groups varied from 8 to 33 with the mean being 19 children and the standard deviation 4.6 children.

\section{Observation}

Kindergarten teachers were trained to observe children between September and December 2014. The training included three afternoons of videos of everyday situations and after each training one month practice in their own groups. The observed categories included the general activity in the kindergarten, children's activities, children's object of attention, children's physical activity, children's involvement (Laevers, 2005), emotions, social orientation and the nearest educator's activity. There were altogether 60,454 observations made between January and May 2015. Each group was observed for seven randomly selected 
days, six days from 8:00 to 12:00 and one day from 12:00 to 16:00. The children were observed at five minute intervals by using systematic sampling. The observations were made in children's natural setting during the children's everyday activity including all children's activity, for example, during teaching, outdoors, supported play, basic care, eating, transitions and in free play situations. The observers were not observing their own groups. The mean percentages (the percentage of the observations included each category) were merged with the evaluations of the amount of PD. The observation instrument is available at http://blogs.helsinki.fi/orientate/files/2015/12/obs15.pdf.

\section{Child evaluations}

The educators of the group evaluated children's self-regulation skills, social skills, learning and social orientation. The evaluations were done by using a scale from one ("does not describe the child at all”) to five ("describes the child very well"). The child evaluation data was merged with the evaluations of the pedagogical evaluation. The child evaluation form is available at http://blogs.helsinki.fi/orientate/files/2015/12/child_eval15.pdf.

\section{LE evaluation}

The 179 teams of ECEC practitioners were asked to evaluate 68 statements in a questionnaire concerning the methods and atmosphere in the LE at the moment. They were instructed to fill in the forms in co-operation with their team members and to select their answer in the range from one ("does not describe the LE at all") to five ("describe the LE accurately"). The LE evaluation is an enhancement of the LE evaluation used in the first phase of the project (cf. Reunamo, Lee, Wu, Wang, Mau, and Lin, 2013), where there was one question about documentation. We wanted to look at documentation from different perspectives and included three questions in the 2015 LE about PD. They are: Q2. The educators document the children's activities very much; Q3. The children document their activities very much; Q4. Documentation is exploited in developing and planning the 
activities. The LE evaluation form is available at http://blogs.helsinki.fi/orientate/files/2015/12/LE_eval2015.pdf, and the evaluation of pedagogical documentation items are the second, third and fourth items in the evaluation form.

\section{Ethics}

The observers' and interviewers' training included aspects of respecting children's rights and feelings. The permits for the children to participate in the research were collected from the parents and guardians. Children's names, birthdays, social security numbers or other data, making the identification of the child possible, were not collected. Neither the personal information of the parents nor educators was collected. Each child received a number with which the data merging between observation, interview and skill evaluation was conducted. The research data did not create an identifiable register of the research participants. The participating staff has received feedback on the group activities to help them enhance their work with children. This feedback did not include any identifiable data.

\section{Analysis}

Quantitative analysis of the connections between PD and other ECEC practice, methods and arrangements were conducted using SPSS. First we study the LE connections with correlations. We use partial correlations controlling children's age, because the summary variable of PD correlated somewhat (.211) with children's age. To study the connections between PD and observation with partial correlations controlling age, we use the mean values of children's observations, for example, the mean value of children's involvement (1-5) in all observations. We also use partial correlation controlling children's age in relation with the child evaluations. The evaluation of the amount of PD is an independent measure of the observations. The observers and evaluators were different 
teachers from different kindergartens and had no access to each other's data. When we estimate the statistical significance of the correlations of the PD evaluations and children's observations, we have to keep mind that children in the same group have the same value of PD. This means that we need to be stricter with the statistical significance. We estimate that the statistical significance of .0005 compensates for the same values of PD evaluations for the children in the same group.

\section{Results}

The amount of documentation

By using the ECEC educator's evaluations on the amount of documentation in their LE, we can summarize that in the 179 educator teams (and groups of children) participating in the study, it was most common for the educators to use documentation to record the children's activity and quite rare for the children themselves to document their own activities (Figure 1).

Figure 1 here.

Almost three quarters (76.0\%) of Finnish ECEC educators documented the activities of children at least somewhat, and $8.3 \%$ of the educators described themselves as documenting children's activities a lot. Documentation done by children was rarer than by educators. Less than two fifths (38\%) of Finnish children in the kindergartens documented their activities at least somewhat, and only in $1.7 \%$ of the groups did the children extensively document their activities themselves. Documentation was applied in developing and planning the activities at least to some extent by three fifths (60.9\%) of the teams, and only $4.3 \%$ of all teams used documentation a great deal for the activity of development and planning. These three aspects of PD correlated positively with each other as can be seen in Table 1. The 
connection between educators' documentation and its use for the activity of development and planning was stronger than children's own documentation connection to the two other aspects of documentation.

Table 1 here.

The reliability of the three items is .741 (Cronbach's alpha), which means that the three items describe the same phenomenon well enough. A summary variable of the three items describing different aspects of PD was counted by taking the mean value of the three evaluated items. This summary variable is used in subsequent analysis.

The summary variable of PD correlated with the age of the youngest child in the group .281 and with the age of the oldest child .251. This means that PD is used more in the groups with older children.

\section{Connections between PD and other LE items}

Next we will present the results of our study by discussing the connections between the summary variable of PD and other features of the LE in Table 2.

Table 2 here

Our results show that when documentation is actively applied to the everyday practice in kindergartens, careful and target-oriented planning and development is emphasised. The purpose and the objectives of national and local curricula as well as the children's personal curricula are taken into account in planning the activities and assessing the work. The children participate in the process of planning the activities, while different projects and themes are developed together with them. It appears that the child-centred practice is 
emphasised in those kindergartens, which document a great deal. Children's ideas are often the starting point in the activities, and the educators are able to connect them with pedagogical targets and contents. Rich documentation also correlates with a high level of children's creativity and self-expression: using diverse and long-lasting play and games, drama, music, and media in education is common. The more documentation, the more the processes of children's thinking, problem solving, and meta-cognitive skills (learning to learn) are considered. Children's learning and skill development tend to be evaluated in a versatile way. The amount of PD correlates also with desirable physical LE (space and materials), which engages children in their activities. Dividing children into small and differentiated working and playing groups is preferred. There is also a correlation between PD and informing parents in cooperation. However, because we did not ask, we do not know how much of this cooperation is used as a tool for planning, assessing, interpreting and discussing this education together with the parents, which would be one of the aims of the national curriculum.

There were only two statistically significant negative correlations and they were both at the level of .05 . When there was less documentation the educators evaluated that Educators' improving and development of their own work should be strengthened $(\mathrm{r}=-.184$, $p=015, \mathrm{n}=172$ ). This connection indicates that the staff is aware of their lack of fully utilizing pedagogical development, or that the educators are not able to develop their work, or finally that they do not have the resources for the desired pedagogical development. Less documentation correlated negatively with the statement Children's emotional expression should be more positive $(\mathrm{r}=-156, p=.015, \mathrm{n}=171)$. PD seems to be connected with a better emotional climate in the group.

Connections between PD and the children's observed activities 
The LE evaluation was conducted by the group educators. The observations were conducted by educators from different kindergartens and they had no knowledge of each other's data. The positive correlations found between PD evaluations and children's observed activities can be seen in Table 3 .

Table 3 here.

When we discuss the children's observed activities (Table 3) it can be concluded that using more PD seems to correlate with those children's activities that are usually considered to be features of high quality in ECEC. The observations of 2,276 children revealed that if the documentation is rich, the children's observed emotions were positive: happiness, joy, and satisfaction correlate with the amount of PD.

In groups with more $\mathrm{PD}$, the educators were more often observed as not present during observations. For example, the children could be playing by themselves in another room. This connection could be describing neglect, but when we checked the connections with other variables of adults not being present during observations, it was more often connected with the positive aspects of autonomy and responsibility. The impression of children's autonomy is strengthened by the tendency of the educators to concentrate a little bit more on discussing with other adults. In the groups with more PD, children attend more to other children. The activities are not clearly educator centred. The children seem to manage by themselves, be able to regulate their behaviour appropriately and the importance of peers is highlighted.

A high level of PD correlated somewhat with children doing other activities. This means that children's activity was not included in the list of children's activity categories. In general, this means that children are doing something out of the box, something that could 
not be anticipated beforehand or could not be defined in the observation instrument. A high level of PD is also manifested in the children's amount of free play indoors. If there was more PD there was also a mild tendency for the children to have a greater degree of freedom in their play activities.

PD correlates positively with the children's high level of involvement in the activity. High involvement, according to Laevers (2005), means that children are engaged in more a sustained and intense activity with more concentration, creativity, mental engagement and persistence. High involvement means that children are working in their zone of proximal development (Vygotsky, 1978) and their potential for learning is high.

Table 4 here.

In Table 4 we can see the negative correlations of the amount of PD and children's observed activities. Groups with more PD tend to have fewer neutral, calm or peaceful emotions. There were also fewer angry, frustrated or disappointed emotions. In general, the correlations for positive emotions (happiness, joy, contentedness, surprise, alertness, curiosity or excitement) was $.126(p<.0005, \mathrm{n}=2276)$ and a weak, not statistically significant, negative correlation $(\mathrm{r}=-.036, p=.083, \mathrm{n}=2276)$ with negative emotions (anger, disappointment, frustration, disgust, contempt, fear, nervousness, sadness and depression).

The amount of PD is negatively correlated with the child observation and the educators tend to have fewer contacts with one child at a time. These results confirm the impression of the positive correlations that in these groups children tend to be more autonomous and self-reliant. However, we need to be careful with this conclusion. At least for some children, it may be that the correlation describes neglect. It is possible that the 
children who need support from the educator are not able to get it easily. This connection remains ambivalent.

The PD connection with the amount of basic care is negative, which is also difficult to explain. Furthermore, in the groups with more PD the children tend to do fewer activities that are defined by the general activity. This means that the group's general activity defines children's personal activity less. The observers used the category General action only if the children's activity could not be separated from the group activity, for example they did tasks as instructed, ate during lunch or dressed up during basic care. This connection means that children were doing things that included some elements they had themselves added to the group activity. Children had a tendency to have more personal activities than in the groups with less PD. It may be (but is highly speculative) that less observed basic care activities are the result of fewer rote activities or basic care activities with more versatile conducting. Connections between PD and the children's evaluated skills and qualities

The educators evaluated children's skills on a scale from one to five. The evaluators of children's skills were the same educators that evaluated the amount of PD in the group. The statistically significant correlations between PD and children's skills are presented in Table 5.

Table 5 here.

The strongest positive correlation is between PD and the evaluated safe attachment in the personnel of the kindergarten. Safe attachment may be acute, especially when we consider the smallest children or children changing kindergarten or children changing groups. The positive correlation between the amount of PD and children's adaptation, openness and mindfulness in interaction highlight the sensitive interaction in the groups. These connections 
can work both ways: Perhaps the sensitive interaction increases consideration for children's point of view, which facilitate PD. Or, perhaps the larger amount of PD increases sensitivity in the group. Children in the groups with more PD were also evaluated to be less insistent and self-imposed in their interaction with others. In groups that conducted more PD children were evaluated to be more creative in imaginary play. It is not possible to state that PD increases creativity in imaginary play. It may be possible that because PD is used more, the educators are just more focused on children's personal creations. It is possible that because the educators are documenting children's processes and creations, it just appears that these children are more creative in imaginary play. Either way, because the educators see these children as more creative in pretend play, the educators probably tend to interact more with the creative aspects of play. Even if the evaluations describe only the educators opinions, not the children's real differences, these educators see these children differently, which probably cause the children to interact with the things they perceive. Thus, we can say that increased PD seemed to increase the educators focus on safe, sensitive warm and creative interaction.

\section{Discussion}

When we discuss our findings about the amount of documentation in Finnish ECEC, and to which LE qualities documentation is related, we have to ponder the reliability and validity of the educators' LE evaluations. What do they consider as documentation and plentiful documentation? Knauf (2015), who studied the forms of documentation in German kindergartens, states that the ambiguity of the term documentation leads to two different practices of PD: the diagnostic and evaluative function of children, or understanding and supporting educational processes (see also Moss, 2005; Carr, 2011, p. 3; Lindgren Eneflo, 2014). In Finland documentation is usually understood in three ways: as a tool for collecting evidence about "normal" and "abnormal" development and behaviour of the child (and his or 
her family) in an educator-centred way (Alasuutari \& Karila, 2010; Koivunen \& Lehtinen, 2015, pp. 79-80); as a tool for getting to know and understand the child in a comprehensive way (Keskinen \& Lounassalo, 2011); and mixing these two approaches (Rintakorpi, in pressb) to plan and develop pedagogy from a certain perspective. In the field of ECEC there are "tensions between the normative tendencies of education and the aims of individualising education through documentation" (Alasuutari et al., 2014, p. 118).

We can interpret that the national Finnish ECEC curricula (Stakes, 2004), which emphasise the social pedagogic approach toward education, represent the child-centred, soft, narrative, qualitative, supporting, casual, informal - we do not have an univocal name for it approach to PD, but it is also common that municipal administrators steer the process of PD into a more evaluative and structured direction by equipping the educators with different kinds of formal tools and tasks to ensure the high academic quality of ECE and the school readiness of children (see Rintakorpi, in press-b; Alasuutari et al., 2014, p. 26). Accordingly, the educators who participated in our study understand the concept of documentation in various, and even discordant ways, and for that reason, both the formal and informal constructions of documentation influence our results. In addition, the educators' estimations about the amount of documentation depend on many factors, e.g. how common documentation is gathered in their kindergarten, in general, or in other kindergartens they have experienced and how their own documentation is related to that. Because PD is nowadays highlighted as a favourable method in Finnish ECEC we can assume hat the educators' estimations about the amount of documentation are rather exaggerated than underestimated. The groups varied a lot in their application of PD.

The amount of PD was positively correlated with national, local and personal curricula being implemented carefully and thoughtfully in co-operation with children. The educators of richly documented groups also report that such child-centred methods as 
creativity, problem solving, and long lasting play are preferred in their groups, and the children's thinking and meta-cognitive processes are flourishing. In addition, according to the educators, the child assessment is conducted by using multiple methods. However, we cannot conclude that PD is the cause of deeper planning or participative practices.

Because the same people evaluated the amount of PD and other LE elements, it is possible that these connections describe more the evaluators' opinions than the real activities. However, the correlations between PD evaluations and observations have to describe some real connections, because the instruments were totally independent. The LE evaluations were done by different people, by different instruments, they did not have any knowledge about each other's data and they did not discuss children or pedagogy. Still, we are not able to say that PD causes happier, more joyful, independent and a more involved learning environment with a greater degree of freedom for the children. It is possible that the connection works both ways: a more satisfactory emotional and social LE may increase the amount of PD, for example, by making it more accessible or enjoyable. Play seems to offer children possibilities to relax, develop, explore, learn, interact and express themselves in versatile ways (cf. Kronqvist \& Kumpulainen 2011, p. 8; Johnson, Sevimli-Celek, \& Al-Mansour, 2013). Creativity in imaginary play is related to wellbeing in many ways (Reunamo, Lee, Wang, Ruokonen, Nikkola \& Malmström, 2013).

When we connect these results with the results of our other indicators (child observations and the educators' child evaluations) we can draw a picture, where happy, safely attached and satisfied children engage in planning and developing wide and playful learning processes with educators. This is a vision of PD that is generously promoted in the professional literature (Stacey, 2015; Keskinen \& Lounassalo, 2011; Rinaldi, 1998; Carr, 2011). However, the decreased amount of time that educators spend on attending towards children have some worrisome overtones. If documentation means that the educators 
concentrate on documentation, not on children, the result is alarming. However, the PD connections with sensitivity, richness and safety of interaction give the decreased attention a more positive tone. Even if there is less attention towards children, the attention seems to be deeper and more creative.

Our study also reveals another side of the documentation. Even if the documentation was preferred in the LE, the parents' role remains questionable. Our description of parents as recipients of information does not measure parents' eligible role as active co-constructors of ECEC, which is emphasised both as an objective in the national curriculum (Stakes 2004) and as an outcome of PD in the professional literature (Stacey, 2015; Keskinen \& Lounassalo, 2011; Carr, 2011; Rinaldi, 1998). We need to study this further.

In our study we found that, according to their own evaluation, $39.1 \%$ of ECEC teams did not utilize PD for future planning at all or very little. As in Finland, it is compulsory to compose an individual educational plan (IEP) for each child, together with parents. We can ask with good reason, whether those documents were written, applied in practice, or whether the educators did not consider them as documents when answering the study. It would also be important to know the content of the documents that $75 \%$ of children, according to their educators, recorded about their own activities at least to some extent. It may be that the educators count, for example, children's drawings as part of the documents somewhat uncritically. In the end, we have to keep in mind that in general the number of child-produced documents describes only $2 \%$ of groups well.

It may be that when the educators actually adopt the tool of documentation, children may be better equipped with the same tool and it might then become a way to develop and plan the education and practices together. We also discovered that PD is used more in the groups of older children than with the toddlers. That is a pity, because PD opens many possibilities to communicate and develop child-centred pedagogy with the youngest children 
as well as with their parents (Rintakorpi, et al., 2014). The child's secure attachment to the educators requires responsiveness, sensitivity, and adaptation to the child's feelings and behaviour (Rusanen 2011, pp. 93-95, 98-99). Safe attachment to caregivers constitutes the ground for the child's healthy growth and wellbeing (Rusanen, 2011, p. 6). We did not find evidence of PD's use with children with special needs or children with immigrant background. Although, we know for example that a lot of pictures, photographs, and written notes are - and have for years been - used with those children and families. Possibly the question is about differences in pedagogical cultures: the educators of those children might consider PD so self-evident that they did not add it into the documentation.

Our study shows that, despite national steering, PD is not fully utilized in Finnish ECEC. However, we found that when it is implemented generously, it seems to relate to the child-centred ECEC practices, such as long-lasting play, creativity, and participation in planning and developing different themes and projects together with educators. If there is more PD, the children's ideas are often a starting point for the activities but also national, local, and individual curricula play an important role in planning and developing ECEC. Children's wellbeing, for example safe attachment in the educators, happiness, and joy are related with plentiful PD. Also children's thinking, learning, and meta-cognitive skills are flourishing and their level of involvement is high, if PD is plentiful.

Our study shows that plentiful PD is connected with methods that are, in general, favourable from the perspective of developing and regenerating the institutional ECEC practice from the viewpoint of the child's wellbeing and learning. However, to achieve PD with high quality, reliability, and validity it would be very important to support the educators in gaining knowledge, achieving skills, and having a professional discourse related to PD. We cannot state that PD creates positive LE, but we can say that PD seems to be related to the more positive aspects of LE. 


\section{References}

Alasuutari, M. (2015). Documenting napping: The agentic force of documents and human action. Children \& Society 29: 219-230. doi:10.1111/chso.12111

Alasuutari, M., \& Karila, K. (2010). Framing the picture of the child. Children and Society, 24: $100-111$.

Alasuutari, M., Markström, A-M., \& A-C. Vallberg-Roth. (2014). Assessment and documentation in early childhood education. Abingdon: Routledge.

Bennett, J. (2010). Pedagogy in early childhood services with special reference to Nordic approaches. Psychological Science and Education, 3: 16-21.

Blaiklock, K. E. (2008). A Critique of the use of learning stories to assess the learning dispositions of young children. NZ Research in Early Childhood Education Journal, 11: 77-87.

Carr, M. (2011). Assessment in early childhood settings: Learning stories. London: Sage.

Carr, M. \& Lee, W. (2012). Learning stories: Constructing learner identities in early education. London: Sage.

Clark, A. (2010). Young children as protagonists and the role of participatory: Visual methods in engaging multiple perspectives. American Journal of Community Psychology 46: 115-123. doi: 10.1007/s10464-010-9332-y

Dahlberg, G., Moss, P., \& Pence, A. (2007). Beyond quality in early childhood education and care: Languages of evaluation. Abingdon: Routledge.

Emilson, A., \& Pramling Samuelsson, I. (2014). Documentation and communication in Swedish preschools. Early Years: An International Research Journal, 34: 175-187. doi: 10.1080/09575146.2014.880664

Ferraris, M. (2013). Documentality: Why it is necessary to leave traces. (R. Davies, Trans.) New York: Fordham University Press.

Fleer, M. \& Hedegaard, M. (2010). Children's development as participation in everyday practices across different institutions. Mind, Culture, and Activity 17, 149-168. doi: $10.1080 / 10749030903222760$ 
Johnson, J.E., Sevimli-Celik, S., \& Al-Mansour, M. (2013). Play in early childhood education. This is a chapter. In Handbook of Research on the Education of Young Children, edited by Saracho, O.N., \& Spodek, B. (pp. 265-274). New York and Oxon: Routledge.

Keskinen, R. \& Lounassalo, J. (2011). Pedagoginen dokumentointi. Leppoistava osallisuuden mahdollistaja. [Pedagogical documentation. How to make participation possible in a balmy way.] This is a chapter. In Löytöretkellä osallisuuteen [Exploring the participation in ECEC], edited by Mäkitalo, A-R., Nevanen,S., Ojala, M., Tast, S., Venninen, T., \& Vilpas, B. (pp. 199-216). Soccan ja Heikki Waris -instituutin julkaisusarja nro 25.

Knauf, H. (2015). Styles of documentation in german early childhood education, Early Years 35, 232-248. doi: 10.1080/09575146.2015.1011066

Koivunen, P-L. \& Lehtinen, T. (2015). Kasvu kiikarissa. Havainnoinnin käsikirja varhaiskasvattajille. [Focusing on the growth. Handbook of observation for ECEC educators]. Jyväskylä: PS-kustannus.

Kronqvist, E-L., \& Kumpulainen, K. (2011). Lapsuuden oppimisympäristöt. Eheä polku varhaiskasvatuksesta kouluun. [The learning environments of the childhood. Harmonious path from early childhood education to school.] Helsinki: WSOYpro Oy.

Laevers, F. (Ed.). (1994). The innovative project experimental education and the definition of quality in education. Defining and assessing quality in early childhood education, (pp. 159-172). Leuven: Leuven University Press.

Lenz Taguchi, H. (2000). Emansipation och motstånd. Dokumentation och kooperativa läroprocesser i förskolan. [Emansipation and resistance. Documentation and cooperative learningprocesses in pre-school.] HLS Förlag. Lärärhögskolan i Stockholm. [Stockholm University, department of teacher education.] Studies in Educational Sciences 33. Available at http://www.divaportal.org/smash/get/diva2:484893/FULLTEXT01.pdf [date last accessed 9 January 2016].

Lindgren Eneflo, E. (2014). Dokumentationens dilemman. Förskollärare samtalar om pedagogisk documentation. [The dilemma of documentation. Preschool teachers discussing pedagogical documentation.] Institutionen för tillämpad utbildningsvetenskap. Licentiatuppsats nr 17 i Pedagogiskt arbete. Umeå 
Universitietet. Available at http://umu.diva-portal.org/ [date last accessed 9 January 2016].

Moss, P. (2005). Making the narrative of quality stutter. Early Education \& Development, 16(4), pp. 405-420.

OECD. (2011). Starting Strong III. A Quality toolbox for early childhood education and care. doi: $10.1787 / 9789264123564-e n$

Project Zero. (2001). Making learning visible. Children as individual and group learners. Reggio Emilia: Reggio Children.

Reunamo, J., Lee, H-C., Wang, L-C., Ruokonen, I., Nikkola, T., \& Malmstrom, S. (2014). Creativity in day care. Early Child Development and Care, 184(4), 617-632.

Reunamo, J. T., Lee, H-C., Wu R., Wang, L-C., Mou, W-Y., \& Lin C-J. (2013). Perceiving change in role play. European Early Childhood Education and Research Journal. 21(2), 292-305.

Rinaldi, C. (1998). Projected curriculum constructed through documentation: Progetazzione. An interview with Lella Gandini. This is a chapter. In The hundred languages of children: The Reggio Emilia approach-Advanced Reflections, edited by Edvards, C., Gandini, L., \& and Forman, G. (pp. 113-157). Westport: Ablex Publishing Corporation.

Rintakorpi, K., Lipponen, L., \& Reunamo, J. (2014). Documenting with parents and toddlers: a Finnish case study. Early Years Journal: An International Research Journal, 34, pp. 188 - 197. doi:10.1080/09575146.2014.903233

Rintakorpi, K. (2016). Documenting with early childhood education teachers: Pedagogical documentation as a tool for developing early childhood pedagogy and practices. Early Years. Published online February 2016. doi: 10.1080/09575146.2016.1145628

Rintakorpi, K. In press-b. Brave like a spider! Pedagogical documentation as a tool in assessing individual learning processes in pre-primary education. Ethnography and Education.

Rusanen, E. (2011). Hoiva, kiintymys ja lapsen kehitys. [Care, attachment, and the child's development]. Helsinki: Oy Finn Lectura Ab. 
Schiller, W., \& Einarsdottir, J. (2009). Editorial. Special issue: Listening to young children's voices in research -changing perspectives/changing relationships. Early Child Development and Care 179: 2, 125-130.

Schultz, M. (2015). The documentation of children's learning in early childhood education. Children \& Society 29, 209-218. doi: 10.1111/chso.12112

Stacey, S. (2015). Pedagogical documentation in early childhood. Sharing children's learning and teacher's thinking. St. Paul, MN: Redleaf Press.

Stakes 2004. National curriculum guidelines on early childhood education and care in Finland. Available at http://urn.fi/URN:NBN:fi-fe201204193910 [date last accessed 9 January 2016].

Vygotsky, L. (1978) Mind in society. Cambridge: Harvard University Press. 
Table 1. The correlations between each item of documentation

\begin{tabular}{llll}
\hline & $\begin{array}{l}\text { The educators } \\
\text { document children's } \\
\text { activities a lot }\end{array}$ & $\begin{array}{l}\text { Children } \\
\text { document their } \\
\text { activities a lot }\end{array}$ & $\begin{array}{l}\text { Documentation is used a } \\
\text { lot for activity } \\
\text { development and } \\
\text { planning }\end{array}$ \\
\hline $\begin{array}{l}\text { The educators document } \\
\text { children's activities a lot }\end{array}$ & 1 & $.436^{* *}(\mathrm{~N}=179)$ & $.554^{* *}(\mathrm{~N}=179)$ \\
$\begin{array}{l}\text { Children document their } \\
\text { activities a lot }\end{array}$ & $.436^{* *}(\mathrm{~N}=179)$ & 1 & $.479 * *(\mathrm{~N}=179)$ \\
$\begin{array}{l}\text { Documentation is used a } \\
\text { lot for activity development } \\
\text { and planning }\end{array}$ & $.554^{* *}(\mathrm{~N}=179)$ & $.479 * *(\mathrm{~N}=178)$ & 1 \\
\hline$* *$ Spearman correlations are statistically significant at the.0005 level (2-tailed).
\end{tabular}


Table 2. The positive correlations between PD and other LE items

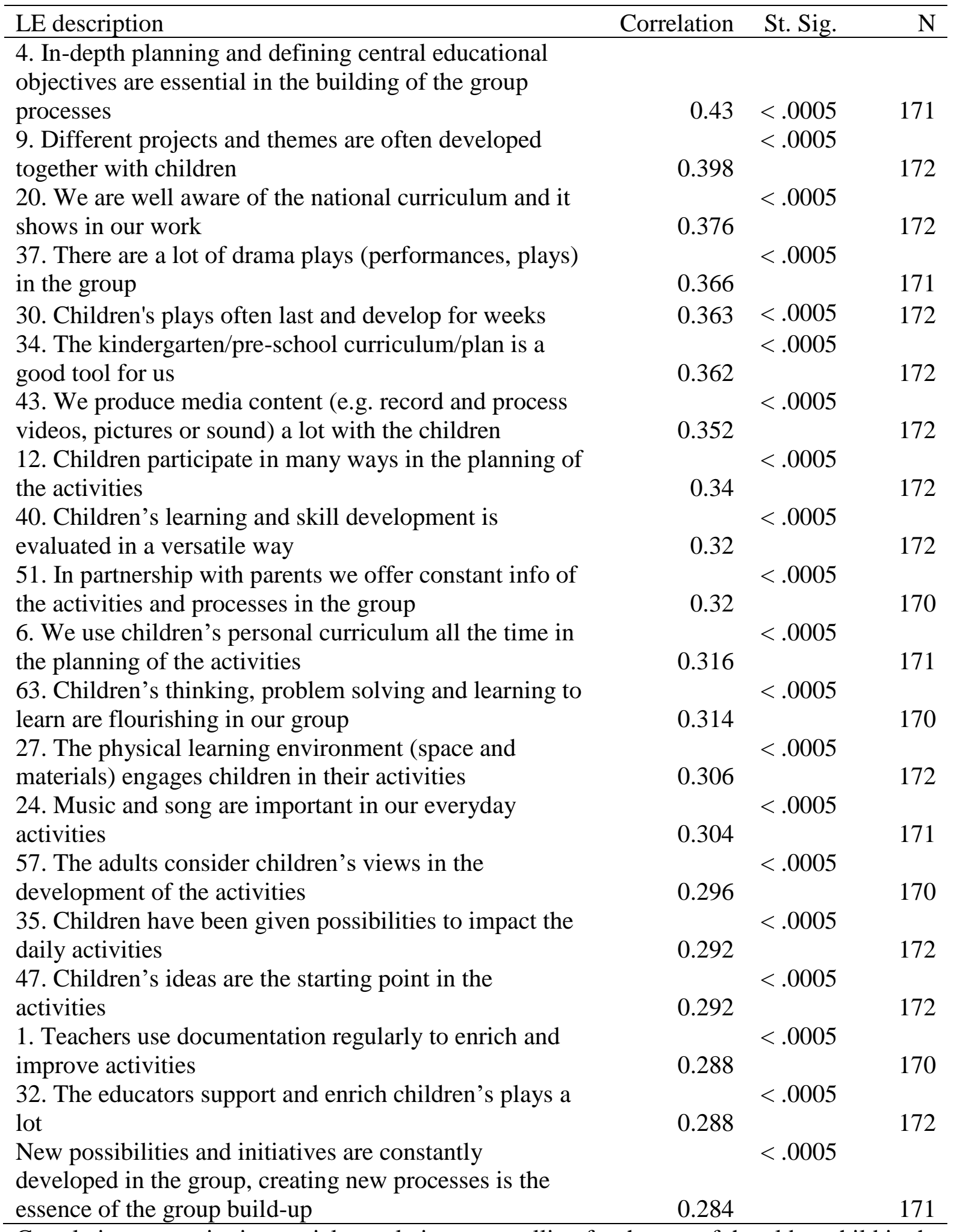

Correlations are pairwise partial correlations controlling for the age of the oldest child in the group 
Table 3. The positive correlations between documentation and the children's observed activities

\begin{tabular}{lllc}
\hline Description & Correlation & St. Sig. & N \\
\hline $\begin{array}{l}\text { G. The child's emotion: happiness, joy, satisfaction (\% of } \\
\text { all observations) }\end{array}$ & 0.12 & $<.0005$ & 2276 \\
$\begin{array}{l}\text { I. The activity of the nearest adult: No adults present (\% } \\
\text { of all observations) }\end{array}$ & 0.106 & $<.0005$ & 2276 \\
$\begin{array}{l}\text { C. The child's main object of attention: Another child (\% } \\
\text { of all observations) }\end{array}$ & 0.088 & $<.0005$ & \\
$\begin{array}{l}\text { F. The child's involvement in the activity (1-5) } \\
\begin{array}{l}\text { B. The content of the child's activity: Other activity that } \\
\text { does not fit into other categories (\% of all activity) }\end{array}\end{array}$ & 0.068 & $<.0005$ & 2276 \\
$\begin{array}{l}\text { I. The activity of the nearest adult: No child contact, but a } \\
\text { contact with another adult (\% of all observations) }\end{array}$ & 0.054 & 0.01 & 2276 \\
\begin{tabular}{l} 
A. What the child is supposed to do: Free play inside. \\
\hline
\end{tabular} & 0.043 & 0.014 & 2276 \\
\hline
\end{tabular}
Correlations are listwise partial correlations controlling for children's age 
Table 4. The negative correlations between PD and the children's observed activities

\begin{tabular}{lccc}
\hline & Correlation & $\begin{array}{l}\text { St. } \\
\text { sig. }\end{array}$ & N \\
\hline $\begin{array}{l}\text { G. The child's emotion: Neutral, calm, peaceful (\% of all } \\
\text { emotions) }\end{array}$ & -0.108 & 0 & 2276 \\
$\begin{array}{l}\text { I. The activity of the nearest adult: No contact with a } \\
\text { child but observes children (\% of all adults' activity) }\end{array}$ & -0.096 & 0 & 2276 \\
$\begin{array}{l}\text { G. The child's emotion: Anger, frustration, } \\
\text { disappointment (\% of all emotions) }\end{array}$ & -0.07 & 0.001 & 2276 \\
$\begin{array}{l}\text { A. What the child is supposed to do: Basic care situations } \\
\text { (e.g., dressing or undressing (\% of all general activities) }\end{array}$ & -0.067 & 0.001 & 2276 \\
$\begin{array}{l}\text { I. The activity of the nearest adult: Interaction with one } \\
\text { child (\% of all adults' activities) }\end{array}$ & -0.064 & 0.002 & 2276 \\
$\begin{array}{l}\text { B: The content of the child's activity: General action. The } \\
\text { child does what it is supposed to in basic care situations, } \\
\text { e.g. dresses or undresses (\% of all child's activities) }\end{array}$ & & & \\
\hline
\end{tabular}

Correlations are listwise partial correlations controlling for children's age 
Table 5. The positive and negative correlations between PD and children's evaluated skills and qualities

\begin{tabular}{lrrr}
\hline Description & Correlation & St. Sig. & N \\
\hline $\begin{array}{l}\text { The child is safely attached in the personnel of the } \\
\text { kindergarten }\end{array}$ & 0.095 & 0 & 1839 \\
$\begin{array}{l}\text { The child is creative in imaginary play } \\
\begin{array}{l}\text { The child is adaptive, open and mindful in interaction with } \\
\text { others }\end{array}\end{array}$ & 0.058 & 0.013 & 1839 \\
$\begin{array}{l}\text { The child is insistent and self-imposed in interaction with } \\
\text { others }\end{array}$ & 0.056 & 0.017 & 1839 \\
\hline
\end{tabular}

Correlations are listwise partial correlations controlling for children's age 


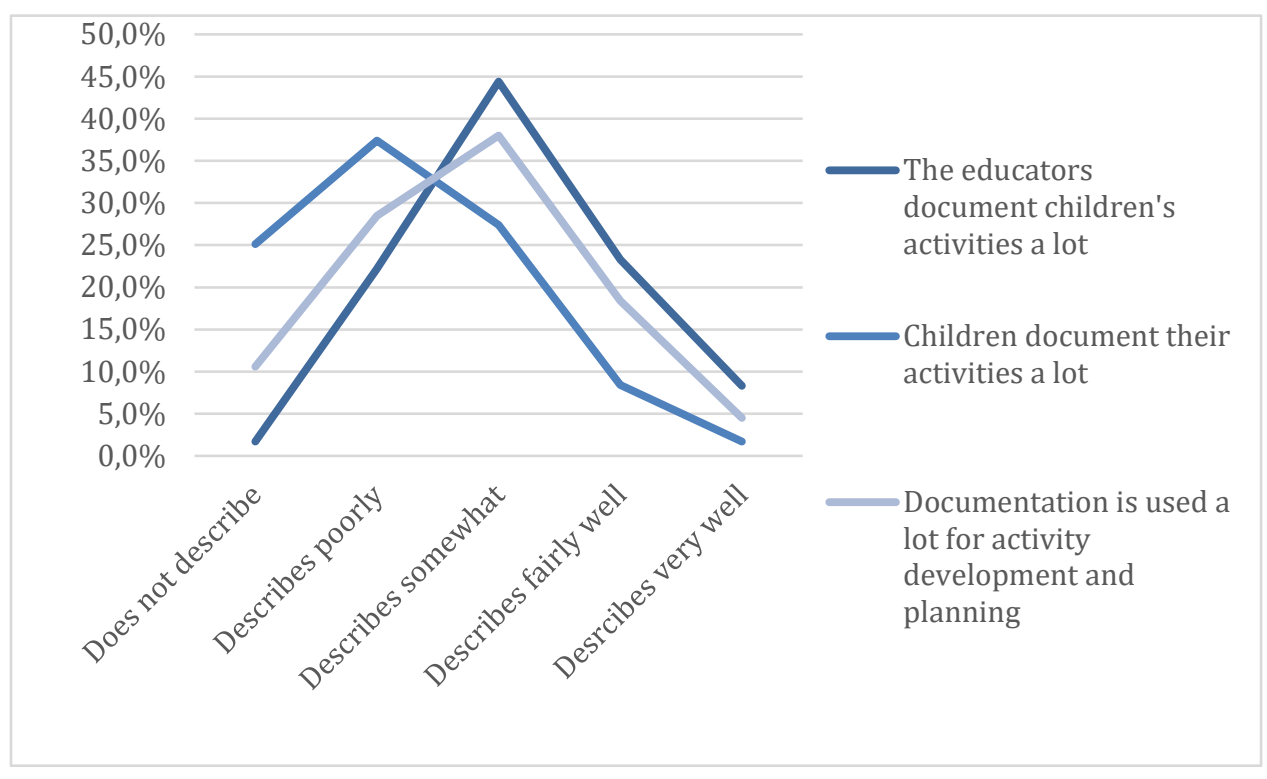

Figure 1. The distribution of the three statements of PD evaluation 